\title{
Chapter
}

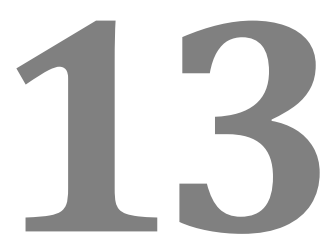

\section{INHIBITION OF BACTERIAL STRESS RESPONSES - STATE OF THE ART}

Nguyen Thi Thu Hoai ${ }^{*}$, Nguyen Trong Thuc ${ }^{1}$, and Peter Lambert ${ }^{2}$

${ }^{1}$ School of Biotechnology, International University, Vietnam National University of Ho Chi Minh City, Vietnam

${ }^{2}$ School of Life and Health Sciences, Aston University, Birmingham, United Kingdom 


\section{Contents}

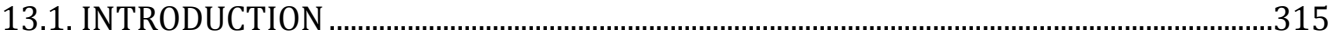

13.2. BACTERIAL STRESS RESPONSES AND THEIR IMPACT ON ANTIMICROBIAL RESISTANCE 315

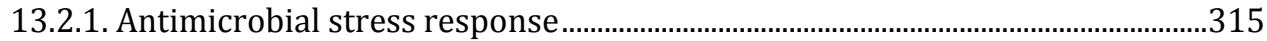

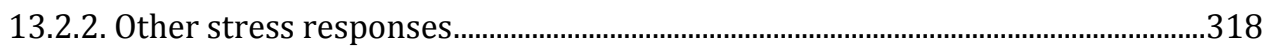

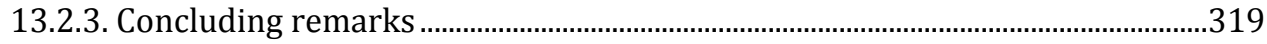

13.3. INHIBITION OF THE ANTIMICROBIAL STRESS RESPONSE …...........................................324

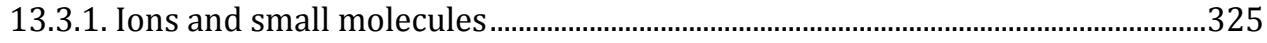

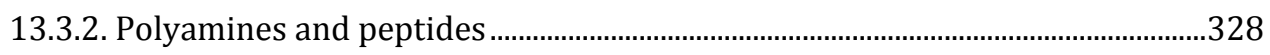

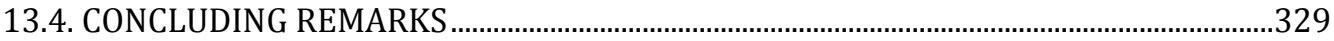

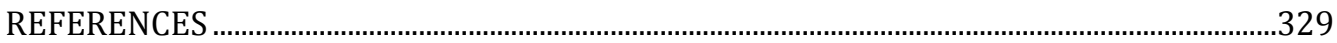




\subsection{INTRODUCTION}

Microorganisms are amazing, not only for the ability of different species to survive and grow in almost all places in this world, but also in the flexibility of species to respond and adapt to multiple adverse environmental stressors, such as extreme temperature/pH/osmotic pressure, nutrient starvation, and presence of toxins like antimicrobial agents. Adaptation via environmental sensing involves a complex transcriptional regulatory network that enables microorganisms to systematically alter expression of a wide variety of genes, enhance frequency of mutations facilitating the appearance of beneficial ones, and promote microbial collaboration to ensure their survival and growth. In this chapter, we will first provide an overview of up-to-date understanding of bacterial stress responses with focus on antimicrobial stress and, second, summarise efforts to inhibit antimicrobial stress response as a potential way to fight antimicrobial resistance (AMR).

\subsection{BACTERIAL STRESS RESPONSES AND THEIR IMPACT ON ANTIMICROBIAL RESISTANCE}

\subsubsection{Antimicrobial stress response}

AMR, the ability of microbes to resist the effect of drugs working against them, is now a serious global problem threatening public health regardless of borders. Without effective antimicrobials, the success of major surgery, cancer therapy, and control of community-acquired infections would be strongly reduced. However, it has been observed that sooner or later after the introduction of new antibiotics, resistance in bacterial isolates will arise. One factor that contributes significantly to this issue is the activation of the stress response in the presence of antimicrobials. For example, with Pseudomonas aeruginosa infections, aminoglycosides such as tobramycin or amikacin are frequently used. Although the most common mechanism of aminoglycoside resistance involves aminoglycoside-modifying enzymes encoded by transmissible genes that are acquired by horizontal gene transfer [1], the predominant resistance mechanisms occurring in persistent bacterial infections in response to antibiotic treatment, such as in case of cystic fibrosis, is impermeability-type pan-aminoglycoside resistance. This involves the MexXY-OprM multidrug efflux system and lipopolysaccharide (LPS) modification [2], which is regulated by the PhoPQ two-component system (TCS), an important sensor in multiple stress responses [3]. PhoPQ TCS, consisting of histidine kinase, $\mathrm{PhoQ}$, and the response regulator, PhoP, are also 
known to respond to cationic antimicrobial peptides such as polymyxin $\mathrm{B}, \mathrm{pH}$, and divalent ion starvation such as $\mathrm{Ca}^{2+}$ and $\mathrm{Mg}^{2+}$. Genes downstream of PhoPQ are responsible for membrane strengthening via phospholipid and LPS modification. PhoP also activates PmrAB TCS, which in turn leads to lipid A modification, resulting in increased hydrophobicity and decreased permeability [4]. Recently, it was reported that PhoPQ also contributes to resistance of pathogens to reactive nitrogen species (RNS) [5].

Two-component systems (TCS) or
two-component regulatory
systems are widely conserved
regulation mechanisms that allow
organisms, particularly bacteria, to
sense and respond to
environmental challenges. They
usually consist of a membrane-
bound histidine kinase responding
to a certain external stimulus and a
cognate response regulator
mediating cellular response via
target gene expression regulation.

One TCS that is also triggered by antimicrobials such as aminoglycosides is CpxRA, an envelope stress TCS. CpxRA comprises a sensor histidine kinase (CpxA) and a cytoplasmic response regulator (CpxR) [6]. It promotes reduced susceptibility to aminoglycosides, beta-lactams, novobiocin, and cationic antimicrobial peptides partly due to CpxRA-dependent upregulation of multidrug efflux, peptidoglycan amidase genes, and porins [7-9].

Another TCS response regulator, AmgrS, which is activated under aminoglycoside exposure, apparently regulates envelope/membrane stress response (ESR). This regulator has been linked to the control of numerous membrane transporters and protease genes whose products can restore aminoglycoside-generated mistranslated polypeptides resulting in aminoglycoside resistance [10]. It is, thus, described as a determinant of intrinsic aminoglycoside resistance [11].

Although TCS is more prevalent in Gram-negative bacteria, TCSs have been increasingly reported in Gram-positive bacteria, among which many are also activated under antimicrobial exposure. For example, CroRS, which is induced under the presence of beta-lactams and other cell wall synthesis inhibitors such as bacitracin, fosfomycin, and vancomycin, is responsible for the production of modified penicillin-binding proteins, thus resulting in betalactam resistance. GrasRS (so called Aps) responding to cationic antimicrobial peptides contributes to resistance to polymyxin B, daptomycin, and vancomycin via membrane modification [12-14]. Two other regulators known to be activated in response to membrane-disrupting agents are LiaRS and NsaRS. These regulate a number of genes, particularly those involved in cellwall synthesis, thus contributing to AMR. Data have shown that mutation of these regulators results in markedly reduced ability to develop AMR $[15,16]$. 
One apparent effect of antimicrobials, particularly the bactericidal agents such as ampicillin, gentamicin, and norfloxacin, is to facilitate the production of reactive oxygen species (ROS) and oxidative stress inside exposed cells, which can kill the bacteria (Dwyer etal. 2014). However, the oxidative stress

Envelope stress response (ESR) or
membrane stress response is a
response to envelop/membrane
damage. It is one of the most important
stress responses in both Gram-negative
and Gram-positive bacteria regarding
the essential function of the bacterial
envelop as a sensor and protective
interface and its vulnerable structure as
the target of numerous harmful factors
including antibiotics. ESR is controlled
mainly by sigma E and the Cpx TCS.

systems such as AcrAB-TolC [20,21], downregulation of the porin OmpF [22], and induce expression of LPS core biosysthesis [23]. Many other efflux systems are known to be induced under oxidative stress including: MexAB-OprM efflux via MexR [24]; NorA/B, Tet38 via MgrA, or SarZ [25,26]; MexXY-OprM via PA5471 [27]; and MexEF-OprN via MexT [28].

Besides the various antimicrobial-induced responses that are responsible for AMR development mentioned above, genomic/transcriptomic investigations have also shown that antibiotics are able to induce expression of various gene classes associated with the SOS response [29-31], heat shock [32-34], acid stress response [35], and multiple other genes involving in metabolism and virulence [36]. Ciprofloxacin, for instance, induced genes for the SOS response, including dnaT, rimM, and recN, genes for cytolysis, genes for biofilm formation, genes of the tricarboxylic acid (TCA) cycle, and multiple other genes that contribute to the resistance to ciprofloxacin and other antibiotics [29-31]. Sub-inhibitory concentrations of streptomycin and beta-lactam antibiotics were shown to successfully induce DnaK and GroEL, two principal heat shock proteins that enable bacteria to tolerate high temperatures [33]. In response to tobramycin, the expression of a number of heat shock genes are induced, particularly in anaerobic conditions under processes requiring the presence of the heat shock sigma factor $\mathrm{RpoH}$ [34]. In this study, marked alteration in the expression of multiple gene groups under the presence of tobramycin was shown [34]. Recent genome-wide transcriptional analysis of the response in $E$. coli to antibiotics of diverse mechanisms of action, trimethoprim (folate synthesis inhibitor), tetracycline (30S inhibitor), nitrofurantoin (a RNS), and chloramphenicol (50S inhibitor), found that they induce diverse gene expression changes with variable levels [35]. While $20 \%$ of the 1,000 tested 
library promoters were up- or down-regulated by more than 2-fold for trimethoprim and tetracycline, only $5 \%$ responded to chroramphenicol. The early oxidative response was observed to be triggered by tetracycline and nitrofuratonin while the delayed SOS response was induced by trimetroprime and nitrofuratonin. Furthermore, a clear and strong acid stress response was induced by trimethoprim, which then proved to protect the bacteria from subsequent $\mathrm{HCl}$ challenge [35].

Overall, it is undeniable that antibiotics can trigger bacterial responses that can lead to alteration of cell physiology, affecting not only its ability to resist antibiotics but also its virulence and fitness upon subsequent environmental challenge. This kind of cross-protection certainly can complicate bacterial infection treatment not only in terms of resistance to antibiotic therapy but also in the way that pathogens develop resistance to the host immune system and increase their virulence.

\subsubsection{Other stress responses}

As antimicrobials are only one of various environmental challenges exerted upon bacteria and, generally, all responsive adaptations of bacteria are in a complex unified network, response to stress stimuli other than antimicrobials will have an impact on antimicrobial susceptibility.

One common environmental challenge to bacteria is nutrient starvation, which is widely accepted as a promoting factor, causing bacteria to become highly tolerant to antimicrobials [37]. For instance, it has been observed that amino acid starvation can result in resistance to ampicillin and ofloxacin; while depletion of glucose leads to resistance to protein synthesis inhibitors such as gentamicin [38]. It was also observed in many bacterial pathogens, such as Mycobacterium tuberculosis, Pseudomonas aeruginosa, and biofilm producers, that oxygen limitation is an important factor inducing AMR [39-41], and introducing oxygen to anoxic ones can increase their susceptibility to antimicrobials [42]. In a number of bacteria, low levels of divalent cations, particularly $\mathrm{Mg}^{2+}$, can significantly reduce their antimicrobial susceptibility [43]. This is explained by the fact that divalent cations have a central role in stabilising bacterial membranes.

Mechanisms leading to starvation-induced AMR are thought to inlcude the inactivity of antibiotic targets caused by starvation-induced growth arrest and, at the same time, an active response to starvation, starvation stress response, or stringent response. It is known that deficiency in carbon, amino acids, and iron activates relA and spot, which results in production of the alarmone, (p)ppGp. This signal, in turn, leads to altered expression of a wide range of genes, including those responsible for AMR. It has been shown that inactivating the starvation stress response, via disrupting relA or spoT for example, can markedly enhance the efficacy of antibiotics [44]. 
Sub-lethal stresses of $\mathrm{pH}, \mathrm{NaCl}$, temperature, or metals also significantly alter antibiotic resistance. A study on food-related pathogens including Escherichia coli, Salmonella enterica serovar Typhimurium, and Staphylococcus aureus showed that, while reduced $\mathrm{pH}(<5.0)$ and increased salt $(>4.5 \% \mathrm{w} / \mathrm{v})$ increased AMR, sub-lethal high temperature $\left(45^{\circ} \mathrm{C}\right)$ decreased it [45]. The observed decrease was probably due to the fact that, in this study, bacteria were incubated at high temperatures $\left(45^{\circ} \mathrm{C}\right)$ for a longer time, indicated as "until no increase was observed in optical density (OD) readings", than in other studies on heat shock (cultured at optimal temperature followed by $30 \mathrm{~min}$ at $40-45^{\circ} \mathrm{C}$ ). Temperature stress in the form of heat shock generally induces AMR. A study in E. coli showed that expression of ClpL, a major heat shock protein induced PBP2x expression, resulted in reduced penicillin susceptibility [46]. A heat shock of $45^{\circ} \mathrm{C}$ for $30 \mathrm{~min}$ on $A$. baumannii also increased survival of the bacteria under streptomycin exposure, which seemed linked with DnaK and GroEL, two important heat-shock proteins [33].

Although some metals, like $\mathrm{Cu}$ and $\mathrm{Zn}$, are essential for microbial growth, at high concentrations they can be toxic or exert selective pressures on bacteria, which could produce multidrug resistance profiles including resistance against carbapenems and third generation cephalosporins [47]. Interestingly, the applied sub-lethal stress was shown to induce stable increases in AMR.

\subsubsection{Concluding remarks}

Antimicrobial and non-antimicrobial stress responses have a strong impact on the development of AMR, which can have serious effects on treatment due to failure of antibiotic therapy. A better understanding of stress response networks and the specific genes involved would be very important in order to target them therapeutically.

In addition to the target proteins mentioned above, it would be a big mistake not to mention essential controllers for gene expression, which are RNA polymerase and corresponding sigma factors. The association/disassociation of these two proteins determines the transcriptional level of a gene. Under specific conditions, a certain sigma factor can integrate with RNA polymerase to form an active holoenzyme that is able to recognise a certain promoter site and transcribe subsequent genes. Most bacteria have a number of sigma factors responding to particular stresses and directing RNA polymerase to transcribe required target genes. Apart from primary or housekeeping sigma factors, which control bacterial growth and metabolism, the alternative ones, such as sigma B (SigB), sigma E (RpoE), sigma S (RpoS), sigma 32 (RpoH), AlgU/T, CarQ, etc., regulate specific physiological processes including general stress responses. Among these alternative sigma factors, the most widespread and important sigma factor group responsible for responding to various dynamic environmental signals is the extracytoplasmic function (ECF) group. Most ECF sigma factors, like sigma E, are transcribed with their cognate 
negative regulators, which bind to and inhibit them and only under environmental stimuli are ECF sigmas released and bind to RNA polymerase to activate transcription of specific target genes [48]. Today, ECF sigma factors are considered regulons for stress survival, virulence, and antibiotic resistance in many pathogens. That a single sigma factor can control a hundred target genes opens the possibility to target sigma factors to regulate systemic cellular reponses, particularly in coping with AMR and virulence developed under antibiotic or environmental stress stimuli.

Over the past years, there has been increasing evidence showing that small, non-coding RNAs or regulatory RNAs are key players in stress reponses, regulating a variety of stress response pathways via transcriptional and post transcriptional control. Regulatory RNAs comprise two major classes, RNA attenuators and small RNAs (sRNAs). Attenuators are transcribed as part of the mRNA they regulate and act via attenuating transcription or translation due to their alteration in secondary structure. sRNAs are expressed independently from their targets and include two types, cis- encoded or antisense sRNAs, which are transcribed from the complementary strand of the target gene, thus fully complementary to their target and trans-encoded sRNAs, which are only partially complementary to their distantly encoded target and often require proteins such as CsrA, Hfq, or ProQ for their activity and function [49]. Hundreds of sRNAs have been found in most bacteria, among those many have been proven to have an essential role in regulating the stress response pathway. RyhB in E. coli, for example, is induced by the transcription factor Fur under iron depletion and its overexpression results in expression change of more than 50 genes involved in iron storage, iron-sulfur biogenesis, ironcontaining proteins, respiration, and siderophore biosynthesis. This effect is mediated by the ability of RyhB to repress target mRNAs of non-essential ironusing proteins, thus freeing irons for essential proteins that rely on iron for their activity [50]. RyhB together with other sRNAs like MicA and RybB contribute to the envelope stress response. These sRNAs, induced by the principal regulator of the envelope stress response sigE, inhibit translation of target mRNAs encoding OMPs and lipoproteins. This kind of regulatory principle is applied for most known sRNAs, including MicF in oxidative, osmolar, and antibiotic stress; OxyS in oxidative stress; SgrS in sugarphosphate stress; DsrA and RprA in acid stress; TisB in SOS response/DNA damage stress; and multiple sRNAs involved in starvation stress [49,50]. It is not surprising that data recently showed that riboregulation exerts a strong impact on antimicrobial susceptibility with its participation in the complex regulatory network controlling drug influx/efflux and drug target modification and metabolism. The pivotal role of regulatory RNAs in antimicrobial susceptibility makes it possible to improve antibiotic usage via combining inhibitors of regulatory RNAs and/or their protein cognate partners, thus silencing corresponding genes involved in AMR. The genes and regulatory 
factors responsible in bacterial stress responses are summarised in Table 1 and present in a networking in Figure 1 (Figure 1, Table 1).

ENVIRONMENTAL STRESS

\begin{tabular}{|llll|}
\hline ANTIMICROBIAL & $\begin{array}{l}\text { NUTRITION } \\
\text { STARVATION }\end{array}$ & pH & $\begin{array}{l}\text { OXIDATIVE/ } \\
\text { NITROSATIVE }\end{array}$
\end{tabular}$\quad$ TEMPERATURE

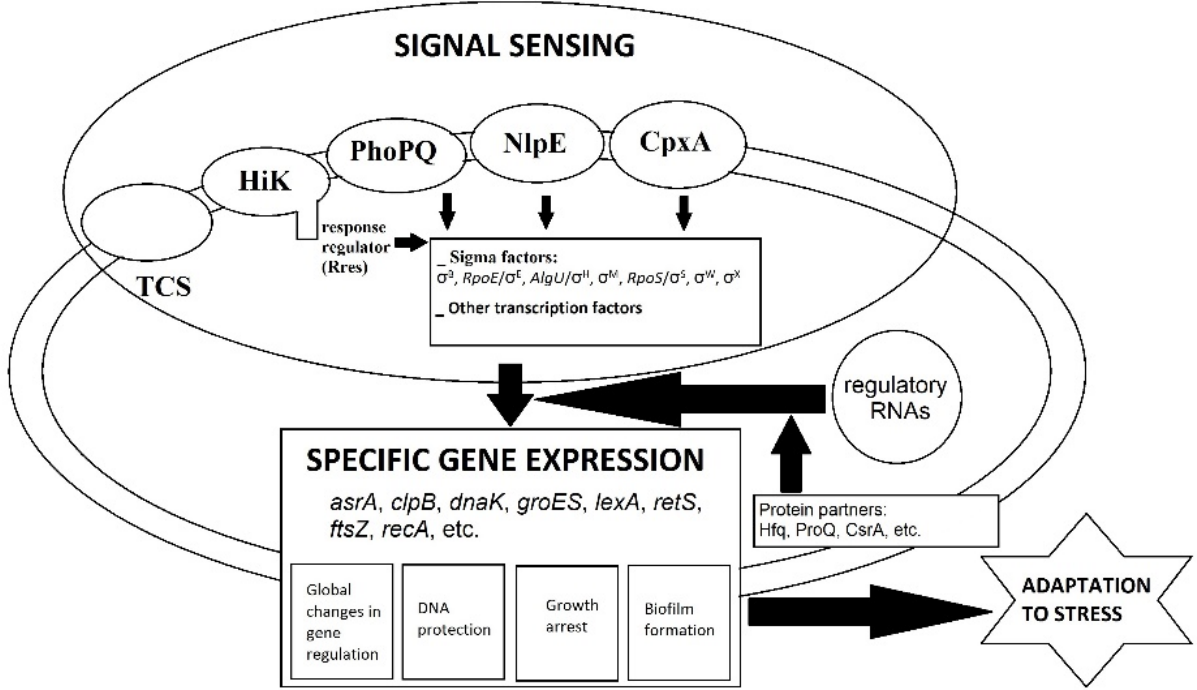

Figure 1. Bacterial stress response network.

Genes responding to antimicrobial stress are highlighted. 
Table 1. Genes involved in bacterial stress response. Genes in human bacterial pathogens and of importance in antimicrobial stress are listed.

\begin{tabular}{|c|c|c|c|c|c|}
\hline Stress & Regulators & $\begin{array}{c}\text { Resistance } \\
\text { mechanisms }\end{array}$ & $\begin{array}{c}\text { Affected } \\
\text { antimicrobials }\end{array}$ & Organisms & Refs \\
\hline \multirow[t]{6}{*}{ Antimicrobials } & AdeRS & AdeABC efflux & $\begin{array}{c}\text { Tigecyclin, } \\
\text { carbapenems, } \\
\text { others }\end{array}$ & $\begin{array}{l}\text { Acinetobacter } \\
\text { baumanni }\end{array}$ & [51] \\
\hline & CpxRA & $\begin{array}{l}\text { AcrBD, eefB } \\
\text { efflux }\end{array}$ & $\begin{array}{c}\text { Beta-lactam, } \\
\text { chloramphenicol }\end{array}$ & $\begin{array}{c}\text { K. } \\
\text { pneumoniae } \\
\text { E. coli }\end{array}$ & $\begin{array}{l}{[9]} \\
{[52]}\end{array}$ \\
\hline & LexA/RecA & QnrB, STX, IntI & Multiple drugs & $\begin{array}{l}\text { Enterobacteri } \\
\text { aceae; Vibrio } \\
\text { sp. }\end{array}$ & {$[53]$} \\
\hline & $\begin{array}{l}\text { PhoPQ/ } \\
\text { PmrAB }\end{array}$ & $\begin{array}{l}\text { Surface } \\
\text { remodeling, } \\
\text { lipid A } \\
\text { modification, } \\
\text { biofilm, } \\
\text { proteolytic } \\
\text { degradation }\end{array}$ & $\begin{array}{l}\text { Colistin, } \\
\text { Polymyxin B }\end{array}$ & $\begin{array}{c}\text { Acinetobacter } \\
\text { baumanii } \\
\text { K. } \\
\text { pneumoniae } \\
\text { P. aeruginosa } \\
\text { S. enterica } \\
\text { S. flexneri }\end{array}$ & $\begin{array}{l}{[54]} \\
{[55]} \\
{[53]} \\
{[56]}\end{array}$ \\
\hline & PhoBR & Porin PhoE & Carbapenems & $\begin{array}{c}K . \\
\text { pneumoniae }\end{array}$ & [57] \\
\hline & VraSR & $\begin{array}{c}\text { Cell wall } \\
\text { biosynthesis } \\
\text { change: PrsA, } \\
\text { FmtA, } \\
\text { glycosyltransfer } \\
\text { ase, TcaA }\end{array}$ & $\begin{array}{c}\text { Beta-lactams } \\
\text { Glycopeptides } \\
\text { Bacitracin }\end{array}$ & S. aureus & $\begin{array}{l}{[58]} \\
{[59]}\end{array}$ \\
\hline \multirow[t]{3}{*}{$\begin{array}{c}\text { Nutrition } \\
\text { starvation } \\
\text { (iron, oxygen, } \\
\text { etc.) } \\
\end{array}$} & SOS/ LexA & $\begin{array}{c}\text { Stress-induced, } \\
\text { mutagenesis, } \\
\text { persisters }\end{array}$ & Fluoroquinolone & E. coli, & {$[53,60]$} \\
\hline & RpoS, RpoE & & Multiple drugs & $\begin{array}{c}\text { E. coli, } \\
\text { M. } \\
\text { tuberculosis } \\
\text { P. aeruginosa } \\
\end{array}$ & $\begin{array}{l}{[61]} \\
{[62]}\end{array}$ \\
\hline & $\begin{array}{l}\text { RelA, SpoT } \\
\text { ((p)ppGp) }\end{array}$ & $\begin{array}{l}\text { Stringent } \\
\text { response- } \\
\text { mediated } \\
\text { amelioration of } \\
\text { antimicrobial- } \\
\text { dependent } \\
\text { oxidative stress }\end{array}$ & Multiple drugs & $\begin{array}{l}\text { P. aeruginosa, } \\
\text { E. coli }\end{array}$ & $\begin{array}{l}{[53]} \\
{[63]}\end{array}$ \\
\hline
\end{tabular}


Table 1. (continued)

\begin{tabular}{|c|c|c|c|c|c|}
\hline Stress & Regulators & $\begin{array}{c}\text { Resistance } \\
\text { mechanisms }\end{array}$ & $\begin{array}{c}\text { Affected } \\
\text { antimicrobials }\end{array}$ & Organisms & Refs \\
\hline \multirow{9}{*}{$\begin{array}{l}\text { Oxidative/ } \\
\text { nitrosative }\end{array}$} & SoxRS & AcrAB-TolC, & Multiple drugs & E. coli, $S$. & [53] \\
\hline & & WaaYZ & & enterica & [64] \\
\hline & PA5471 & MexXY-OprM & Multiple drugs & P. aeruginosa & [53] \\
\hline & & & & & [65] \\
\hline & MexR & MexAB-OprM & Multiple drugs & P. aeruginosa & [53] \\
\hline & & & & & [66] \\
\hline & MgrA/ SarZ & $\begin{array}{c}\text { NorA, NorB, } \\
\text { Tet38 }\end{array}$ & beta-lactams & S. aureus & [67] \\
\hline & MexT & MexEF-OprN & Multiple drugs & P. aeruginosa & [53] \\
\hline & & & & & [68] \\
\hline \multirow{4}{*}{$\begin{array}{l}\text { pH (Acidic, } \\
\text { Alkaline) }\end{array}$} & $\operatorname{SigB}\left(\sigma^{\mathrm{B}}\right)$ & RsbK-RsbY- & beta-lactams, & S. aureus & [53] \\
\hline & & RsbV & glycopeptides & & [69] \\
\hline & $\operatorname{SigE}\left(\sigma^{\mathrm{E}}\right)$ & YaeL-RseA & Kanamycin, & E. coli, & [70] \\
\hline & & & polymyxin B & S. enterica & [71] \\
\hline \multirow{5}{*}{$\begin{array}{l}\text { Temperature } \\
\text { (heat, cold) }\end{array}$} & RpoH, AsrA & Drug-induced & beta-lactams & S. aureus & [53] \\
\hline & & aberrant & & P. aeruginosa & [72] \\
\hline & & $\begin{array}{l}\text { polypeptide } \\
\text { turnover }\end{array}$ & & & \\
\hline & ClpL, PBP2X & PBP2X-mediated & Penicillin, beta- & $S$ & [73] \\
\hline & & $\begin{array}{l}\text { thickening of } \\
\text { cell wall }\end{array}$ & lactams & pneumoniae & [46] \\
\hline
\end{tabular}




\subsection{INHIBITION OF THE ANTIMICROBIAL STRESS RESPONSE}

It is evident that AMR development is unpreventable once antimicrobials are used. In combating AMR, inhibitors of novel targets other than the "established targets" have been sought with little success [74].

Attempts to combat AMR by inhibiting the antimicrobial stress response while using existing antibiotics in a combination therapeutic approach have only recently gained attention. Some progress has been made and this is promising for future developments in this area [22].

Data obtained so far have clearly shown that knock-down or knock-out of important regulators of stress responses significantly enhances activity of existing antimicrobials and reduces the rate of AMR development. For example, blocking the stress regulator AmgRS enhanced aminoglycoside activity in both planktonic and antibiotic tolerant bacteria [22]. Knocking out multiple genes in E.coli, particularly those involved in transcriptional regulation $(\operatorname{deo} T, d k s A)$ or SOS genes $(r e c A, r e c N)$, also increased sensitivity to different classes of antibiotics [75]. In Staphylococcus aureus, inactivation of VraS TCS, an envelope stress regulon, caused a marked reduction in resistance to beta-lactam antibiotics and vancomycins [58,59]. In additoin, inhibition of the SOS response via the RecA/LexA axis rendered S. aureus unable to evolve antibiotic resistance in response to UV damage [29].

In Acinetobacter baumanii, the lack of AdeRS TCS resulted in significantly decreased expression of RND efflux genes, including adeABC which can result in increased sensitivity to a wide range of antibiotics that they control such as aminoglycosides, beta-lactams, tetracyclines, macrolides, and chloramphenicol [51]. In Pseudomonas aeruginosa, mutant strains deficient in rpoS, relA and spoT, or anr, a gene encoding an important mediator of hypoxia stress, had markedly increased susceptibility to ciprofloxacin [31]. Interestingly, recent data also showed that inhibition of the SOS response via disruption of the RecA/LexA axis in E. coli with different established quinolone resistant determinants, such as chromosomal gyrA/parC mutations, marR deletion, and plasmid-mediated quinolone resistance (PMQR) qnrS, can reverse the resistance phenotype and has a fascinating effect in an in vivo murine model with decreased virulence and increased antibiotic susceptibility [76]. Very recently, attempts at interference with sRNA regulatory pathways showed promising results in increasing antimicrobial susceptibility. For example, the absence of MicF increased susceptibility to cephalosporin and norfloxacin; of GcvB, sensitised bacteria to D-cycloserine; of RyhB, reduced resistance to colistin; and of MgrR/SroC, affected polymyxin B resistance [49]. Compounds are known to interfere with bacterial stress responses are summarized in Table 2 and discussed in details in the followed sections. 
Table 2. Compounds with potential to inhibit the bacterial stress response.

Compounds having inhibitory activity on the antimicrobial stress response are highlighted.

\begin{tabular}{|c|c|c|c|}
\hline & Inhibitors & Pathways & References \\
\hline Ions & Zinc & $\begin{array}{c}\text { SOS response } \\
(\text { LexA-RecA) }\end{array}$ & {$[80]$} \\
\hline \multirow[t]{4}{*}{$\begin{array}{c}\text { Small } \\
\text { molecules }\end{array}$} & $\begin{array}{c}\text { 2-aminoimidazole } \\
\text { derivatives, }\end{array}$ & VraSR & [78] \\
\hline & $\begin{array}{c}\text { C1, D1, } \\
\text { Curcumin }\end{array}$ & $\begin{array}{l}\text { SOS response } \\
\text { (LexA-RecA) }\end{array}$ & [87] \\
\hline & $\begin{array}{c}\text { Suramin/germanin } \\
\text { (polysulphonated } \\
\text { naphthyl urea), }\end{array}$ & $\begin{array}{l}\text { SOS response } \\
\text { (LexA-RecA) }\end{array}$ & {$[84,85]$} \\
\hline & $\begin{array}{l}\text { RWJ-49815 (ethyl } \\
\text { guanidine derivative) }\end{array}$ & $\begin{array}{c}\text { Histidine kinases } \\
\text { of TCSs }\end{array}$ & {$[77]$} \\
\hline Polyamine & $\begin{array}{c}\text { Cadaverine, Putrescine, } \\
\text { Spermidine, } \\
\text { Spermine }\end{array}$ & $\begin{array}{c}\text { Oxidative } \\
\text { response } \\
(\text { oxyR-katG) }\end{array}$ & [88] \\
\hline Peptides & $\begin{array}{c}\text { 4E1 (18-aa peptide), } \\
\text { 1018, DJK-5 }\end{array}$ & $\begin{array}{l}\text { SOS response } \\
\text { (LexA-RecA); } \\
\text { Stringent } \\
\text { response-biofilm } \\
\text { ((p)ppGpp) }\end{array}$ & [89-91] \\
\hline
\end{tabular}

\subsubsection{Ions and small molecules}

Early attempts at inhibiting the TCS regulon provided encouraging results. A new class of antibacterials, hydrophobic tyramines, that inhibits the first component of TCS, histidine kinase, has been discovered. Notable representatives are RWJ-49815 and its analogs. They inhibited bacterial growth and expressed reduced emergence of resistance in laboratory passage experiments [77].

Some 2-aminoimidazole-containing compounds that inhibit VraSR TCS were shown to suppress resistance to beta-lactam antibiotics including oxacillin and carbapenems [78].

As mentioned in the stress response section above, sub-lethal metal stresses can induce AMR. However, it has been shown that $\mathrm{Zn}$ or $\mathrm{Mg}$ at optimal concentrations can significantly increase the activity of antibiotics (9$15 \mu \mathrm{g}$ /antibiotic disc; 3-9 $\mu \mathrm{g}$ /antibiotic disc) [79]. Recently, data indicated that $\mathrm{Zn}$ at $0.2 \mathrm{mM}$, for example, can inhibit the SOS response and hypermutation phenomenon in bacteria via interference with the actions of RecA and 
protecting LexA, an initiator of the SOS response, from RecA-mediated cleavage, thereby reducing the rate and magnitude of AMR [80].

Recognising the importance of RecA in AMR development, a study in 2007 screened multiple small molecules for RecA inhibition activity. It found that curcumin and polysulfated naphthyl compounds, including congo red, suramin, and bis-ANS, substantially inhibited RecA's ATPase activity, among which the polysulfated naphthyl compounds seemed to have an effect on ATP hydrolysis activity via direct binding to RecA while curcumin did not [81].

Curcumin, a natural polyphenolic flavonoid derived from Curcuma longa L. or turmeric, is known for various biological activities including antiinflammatory, antioxidant, antibacterial, and wound-healing accelerating activity. The average minimum inhibitory concentration (MIC) values of curcumin against Gram-negative and Gram-positive bacteria were $117.4 \mathrm{mg} \mathrm{L}^{-1}$ and $126.9 \mathrm{mg} \mathrm{L}^{-1}$, respectively [82]. Recent evidence suggested that curcumin at $8 \mathrm{mg} \mathrm{L}^{-1}$ can inhibit the SOS response in E. coli induced by levofloxacin or ultraviolet (UV) irradiation $[83,84]$. The exact mechanism is still unclear but it is suggested that curcumin might have a role in preventing the binding of ssDNA to RecA protein, therefore lowering the SOS response [84]. Furthermore, it was shown that curcumin can trigger a synergistic effect when used together with beta-lactam and quinolone antibiotics, among which ciprofloxacin had maximum synergy for Gram-positive and amikacin, gentamicin, and cefepime for Gram-negative isolates [82]. In addition, it also restored sensitivity of methicillin-resistant Staphylococcus aureus (MRSA) to antibiotics and its actibacterial effect increased markedly when used together with membrane permeability enhancers and ATPase inhibitors [83]. In conclusion, with low toxicity curcumin is suggested to have a beneficial role in supplementing antibiotic therapy.

Suramin (Germanin), a polysulphonated naphthyl urea, inhibits DNA strand exchange, ATPase activities of bacterial RecA, and RecA-catalysed proteolytic cleavage of the LexA repressor. Data showed that suramin abolished ciprofloxacin-induced $\operatorname{recA}$ gene expression and the SOS response and augmented the bactericidal action of ciprofloxacin [86]. Suramin and polysulfated naphthyl compounds, though previously considered to have little therapeutic utility due to their negative charge causing difficulty in crossing cell membranes, have been used to treat parasitic infections (filariasis, trypanosomiasis) and viral infections as well as maglinancies. It is possible that suramin and its derivatives could be developed into adjuvants for antibiotic chemotherapy, which can reduce AMR development.

A high-throughput screening method for RecA/LexA axis inhibitors has recently been developed. It has screened more than 1.8 million compounds and identified new small molecule classes that target the LexA autoproteolysis step in SOS activation. Among those newly-identified compounds, C1 and D1 (Figure 2) showed remarkable inhibition activity [87]. 
<smiles>Cc1ccc(C(=O)Nc2ccc(S(=O)(=O)O)c3cc(S(=O)(=O)O)cc(S(=O)(=O)O)c23)cc1NC(=O)c1cccc(NC(=O)Nc2cccc(C(=O)Nc3cc(C(=O)Nc4ccc(S(=O)(=O)O)c5cc(S(=O)(=O)O)cc(S(=O)(=O)O)c45)ccc3C)c2)c1</smiles>

A) Suramin

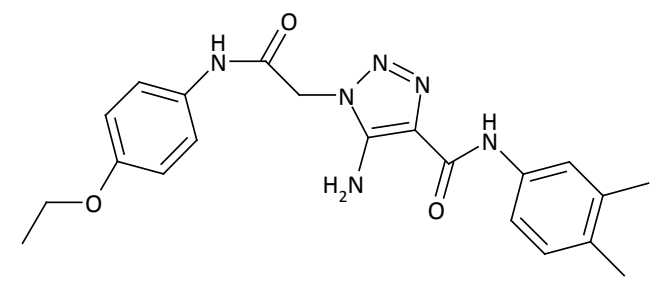

B) C1

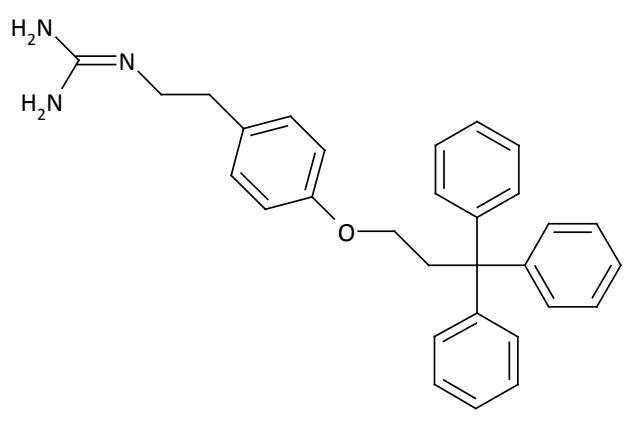

D) TCS inhibitor RWJ-49815<smiles></smiles>

C) D1

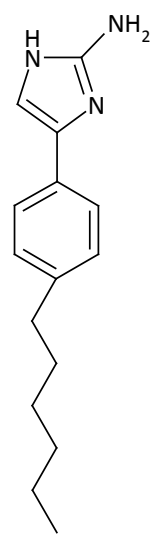

E) 2-aminoimidazole derivatives

Figure 2. Chemical structure of organic compounds with potential to inhibit the bacterial stress response 


\subsubsection{Polyamines and peptides}

Polyamines are organic cationic compounds with two or more primary amino groups. The low-molecular-weight linear polyamines, such as putrescine, spermidine, spermine, and cadaverine, are present in most organisms and perform essential functions including cell growth, survival, proliferation, and stress responses, such as oxidative or antimicrobial stress. Oxidative stress, for example, was reduced via upregulation of oxyR and katG under the effect of either endogenous or exogenous polyamines such as putrescine [88]. Some research also indicated that polyamines affected bacterial adaptations to stress with high involvement of the RpoS pathway [62]. The polyamines cadaverine, putrescine, and spermidine increased rpoS expression, which can result in the reduction of porin permeability as a response to prevent antibiotic penetration into the cell, thus leading to AMR. Exogenous polyamines, however, differently affected antimicrobial susceptibility. While MICs of beta-lactam antibiotics were markedly reduced in the presence of spermine and spermidine, for example 200 folds for oxacillin, the MICs of polymyxin and ciprofloxacin were increased. Synergistic effects of polyamines with antibiotics were proven not to be related to porin and efflux pumps in some cases; however, detailed mechanisms are not yet clear [92].

A recent finding showed that a synthetic peptide, DJK-5, was able to interfere with bacterial stress responses and heal abscesses in mice [91]. This small cationic peptide consisting of D-aminoacids caused rapid degradation of the stringent response mediator, alarmone guanosine tetraphosphate (p)ppGp, resulting in stringent response inhibition. It also had strong antibiofilm activity against different multi-drug resistant Gram-negative bacteria [91]. Similar to DJK-5, synthetic peptide 1018 was also proven to target the same pathway with high involvement to SpoT and RelA. Together, they offer a promising novel therapeutic approach in fighting AMR [90,93].

Not surprisingly, scientists have developed peptide inhibitors of RecA/LexA, undebatably important targets to inhibit SOS response, which is a principal mechanism of bacterial adaptation to antibiotics. According to the sequence of RecX protein, an active natural RecA inhibitor, 20-amino acid alpha helical peptides were designed showing promising in vitro RecA inhibiting activity and in vivo SOS response blocking activity [89].

Lately, developing inhibitors of up-stream regulatory molecules in the stress response network, such as sigma factors and regulatory RNAs, have attracted research interest and produced a few pioneering results. Inhibitors of sigE, for example, have been investigated via high-throughput screening with small cyclic peptides generated in E. coli by using split-intein circular ligation of proteins and peptides (SICLOPPS), a genetic system based on spontaneous protein splicing by inteins. Results showed that some cyclic peptides expressed impressive sigE inhibition activity in vitro but not yet in vivo when added exogenously into bacterial culture as an antibiotic. This is probably due to the 
inability of these cyclic peptides to cross cell envelopes, leading to low intracellular accumulation [94]. The same research group also attempted to find inhibitors for the Hfq-sRNA system, and they found one cyclic peptide, RI20, that is able to inhibit gene expression of Hfq-mediated regulation in cooperation with RybB and MicF [95]. Interestingly, under the presence of RI20, bacterial cells become more susceptible to oxidative stress (challenged with hydrogen peroxide) and antibiotics such as benzalkonium chloride and novobiocin [94].

\subsection{CONCLUDING REMARKS}

Understanding the bacterial stress response creates opportunities to efficiently use existing antibiotics as well as better understand their mechanisms of action. Preliminary success in interfering with stress response pathways brings hope to antibiotic co-therapy, which can enhance antibiotic efficacy and reduce antibiotic resistance development. Recent approaches to develop multiple-target inhibitors or inhibitors of upstream regulators of antimicrobial and antimicrobial-related stress response can reduce the effect of target mutation or systemically impair bacterial physiology. Future research will show whether we can widely apply this approach in clinical settings.

\section{REFERENCES}

1. K. Poole, Agents Chemother. 49 (2005) 479-487.

2. D. Hocquet, A. Muller, K. Blanc, P. Plésiat, D. Talon, D.L. Monnet, X. Bertrand, Agents Chemother. 52 (2008) 1173-1175.

3. E.L. Macfarlane, A. Kwasnicka, R.E. Hancock, Microbiol. 146 (2000) 25432554.

4. J.S. Gunn, S.I. Miller, J. Bacteriol. 178 (1996) 6857-6864.

5. T.J. Bourret, L. Liu, J.A. Shaw, M. Husain, A. Vázquez-Torres, Sci. Reports. 7 (2017) 15083.

6. P.A. DiGiuseppe, T.J. Silhavy, J. Bacteriol. 185 (2003) 2432-2440.

7. E. Batchelor, D. Walthers, L.J. Kenney, M. Goulian, J. Bacteriol. 187 (2005) 5723-5731.

8. M.A. Kohanski, D.J. Dwyer, J. Wierzbowski, G. Cottarel, J.J. Collins, Cell. 135 (2008) 679-690.

9. K. Nishino, S. Yamasaki, M. Hayashi-Nishino, A. Yamaguchi, Antimicrob. Agents Chemother. 54 (2010) 2239-2243.

10. A. Hinz, S. Lee, K. Jacoby, C. Manoil, J. Bacteriol. 193 (2011) 4790-4797.

11. S. Lee, A. Hinz, E. Bauerle, A. Angermeyer, K. Juhaszova, Y. Kaneko, P.K. Singh, C. Manoil, Sci. U. S. A. 106 (2009) 14570-14575.

12. M. Li, D. J. Cha, Y. Lai, A.E. Villaruz, D.E. Sturdevant, M. Otto, Mol. Microbiol. 66 (2007) 1136-1147. 
13. T. Jones, M.R. Yeaman, G. Sakoulas, S.J. Yang, R.A. Proctor, H.G. Sahl, J. Schrenzel, Y.Q. Xiong, A.S. Bayer, Antimicrob. Agents Chemother. 52 (2008) 269-278.

14. S.J. Yang, A.S. Bayer, N.N. Mishra, M. Meehl, N. Ledala, M.R. Yeaman, Y.Q. Xiong, A.L. Cheung, Infect. Immun. 80 (2012) 74-81.

15. S.L. Kolar, V. Nagarajan, A. Oszmiana, F.E. Rivera, H.K. Miller, J.E. Davenport, J.T. Riordan, J. Potempa, D.S. Barber, J. Koziel, M.O. Elasri, L.N. Shaw, Microbiol. 157 (2011) 2206-2219.

16. P.K. Nielsen, A.Z. Andersen, M. Mols, S. van der Veen, T. Abee, B.H. Kallipolitis, Microbiol. 158 (2012) 963-974.

17. F. Lebreton, W. van Schaik, M. Sanguinetti, B. Posteraro, R. Torelli, F. Le Bras, N. Verneuil, X. Zhang, J.C. Giard, A. Dhalluin, R.J. Willems, R. Leclercq, V. Cattoir, PLOS Pathog. 8 (2012) e1002834.

18. Dridi, A. Lupien, M.G. Bergeron, P. Leprohon, M. Ouellette, Antimicrob. Agents Chemother. 59 (2015) 5420-5426.

19. M. Gu, M. \& J.A. Imlay, Mol. Microbiol. 79 (2011) 1136-1150.

20. E. Hartog, L. Ben Shalom, D. Shachar, K.R. Matthews, S. Yaron, Microbiol. Immunol. 52 (2008) 565-574.

21. E. Nikaido, I. Shirosaka, A. Yamaguchi, Microbiol. 157 (2011) 648-655.

22. J.H. Chou, J.T. Greenberg, B. Demple, J. Bacteriol. 175 (1993) 1026-1031.

23. J.H. Lee, K.L. Lee, W.S. Yeo, S.J Park, J.H. Roe, J. Bacteriol. 191 (2009) 44414450.

24. H. Chen, J. Hu, P. R. Chen, L. Lan, Z. Li, L. M. Hicks, A. R. Dinner, C. He, Proc. Natl. Acad. Sci. USA. 105 (2008) 13586-13591.

25. P.R. Chen, T. Bae, W.A. Williams, E.M. Duguid, P.A. Rice, O. Schneewind, C. He, Nat. Chem. Biol. 2 (2006) 591-595.

26. P.R. Chen, S. Nishida, C.B. Poor, A. Cheng, T. Bae, L. Kuechenmeister, P.M. Dunman, D. Missiakas, C. He, Mol. Microbiol. 71 (2009) 198-211.

27. S. Fraud, K. Poole, Antimicrob. Agents Chemother. 55 (2010) 1068-1074.

28. H. Fetar, C. Gilmour, R. Klinoski, D.M. Daigle, C.R. Dean, K. Poole, Antimicrob Agents Chemother. 55 (2011) 508-514.

29. R.T. Cirz, B.M. O’Neill, J.A. Hammond, S.R. Head, F.E. Romesberg, J. Bacteriol. 188 (2006) 7101-7110.

30. R.T. Cirz, M.B. Jones, N.A. Gingles, T.D. Minogue, B. Jarrahi, S.N. Peterson, F.E. Romesberg, J. Bacteriol. 189 (2007) 531-539.

31. P.S. Stewart, M.J. Franklin, K.S. Williamson, J.P. Folsom, L. Boegli, G.A. James, Antimicrob. Agents Chemother. 59 (2015) 3838-3847.

32. K.J. Shaw, N. Miller, X. Liu, D. Lerner, J. Wan, A. Bittner, B.J. Morrow, J. Mol. Microbiol. Biotechnol. 5 (2003) 105-122.

33. K. Cardoso, R.F. Gandra, E.S. Wisniewski, C.A. Osaku, M.K. Kadowaki, V. Felipach-Neto, L.F. Haus, C. Simão Rde, J. Med. Microbiol. 59 (2010) 10611068.

34. K.N. Kindrachuk, L. Fernandez, M. Bains, R.E. Hancock, Antimicrob. Agents Chemother. 55 (2011) 1874-1882.

35. K. Mitosch, G. Rieckh, T. Bollenbach, Cell 4 (2017) 393-403.

36. Y. Morita, J. Tomida, Y. Kawamura, Front. Microbiol. 4 (2013) 422.

37. R.H. Eng, F.T. Padberg, S.M. Smith, E.N. Tan, C.E. Cherubin, Antimicrob. Agents Chemother. 35 (1991) 1824-1828. 
38. K.C. Fung, E.W.C. Chan, M.L. Chin, R.C.Y. Chan, Antimicrob. Agents Chemother. 54 (2010) 1082-1093.

39. T.R. Field, A. White, J.S. Elborn, M.M. Tunney, Eur. J. Clin. Microbiol. Infect. Dis. 24 (2005) 677-687.

40. S.H. Baek, A.H. Li, C.M. Sassetti, PLoS Biol. 9 (2011) e1001065.

41. B. Pabst, B. Pitts, E. Lauchnor, P.S. Stewart, Antimicrob. Agents Chemother. 60 (2016) 6294-6301.

42. M. Kolpen, C.J. Lerche, K.N. Kragh, T. Sams, K. Koren, A.S. Jensen, L. Line, T. Bjarnsholt, O. Ciofu, C. Moser, M. Kühl, N. Høiby, P.Ø. Jensen, Antimicrob. Agents Chemother. 61 (2017) e01024-17.

43. K. Poole, J. Antimicrob. Chemother. 67 (2012) 2069-2089.

44. D. Nguyen, A. Joshi-Datar, F. Lepine, E. Bauerle, O. Olakanmi, K. Beer, G. McKay, R. Siehnel, J. Schafhauser, Y. Wang, B.E. Britigan, P.K. Singh, Science 334 (2011) 982-986.

45. M.A.S. McMahon, J. Xu, J.E. Moore, I.S. Blair, D.A. McDowell, Appl. Environ. Microbiol. 73 (2007) 211-217.

46. T.D.H. Tran, H.Y. Kwon, E.H. Kim, K.W. Kim, D.E. Briles, S. Pyo, D.K. Rhee, Antimicrob. Agents Chemother. 55 (2011) 2714-2728.

47. C. Becerra-Castro, R.A. Machado, I. Vaz-Moreira, C. Manaia, Sci. Total Environ. 530-531 (2015) 367-372.

48. K.J. Boor, PLoS Biol. 4 (2006) e23.

49. P. Dersch, M.A. Khan, S. Mühlen, B. Görke, Front. Microbiol. 8 (2017) 803.

50. E. Holmqvist, E.G.H. Wagner, Biochem. Soc. Trans. 45 (2017) 1203-1212.

51. E.Richmond, L.P. Evans, M.J. Anderson, mBio. 7 (2016) e00430-16.

52. V.B. Srinivasan, V. Vaidyanathan, A. Mondal, G. Rajamohan, PLoS ONE 7 (2012) e33777.

53. K. Poole, Trends Microbiol. 20 (2012) 227-234.

54. K. Barrow, D.H. Kwon. Antimicrob. Agents Chemother. 53 (2009) 5150-5154.

55. N.S. Ly, J. Yang, J.B. Bulitta, B.T. Tsujia. Antimicrob. Agents Chemother. 56 (2012) 3453-3456.

56. V.I. Band, D.S. Weiss, Antibiotics (Basel). 4 (2015) 18-41.

57. M. Kaczmarek, F. Dib-Hajj, W. Shang, T.D. Gootz, Antimicrob. Agents Chemother. 50 (2006) 3396-3406.

58. S. Gardete, S.W. Wu, S. Gill, A. Tomasz, Antimicrob. Agents Chemother. $\mathbf{5 0}$ (2006) 3424-3434.

59. H. Chen, Z. Xiong, K. Liu, S. Li, R. Wang, X. Wang, Y. Zhang, H. Wang, Int. J. Antimicrob. Agents. 47 (2016) 362-367.

60. A. Theodore, K. Lewis, M. Vulic, Genetics. 195 (2013) 1265-1276.

61. K. Murakami, T. Ono, D. Viducic, S. Kayama, M. Mori, K. Hirota, K. Nemoto, Y. Miyake, FEMS Microbiol. Lett. 242 (2005) 161-167.

62. R. Choudhury, S.K. Mohapatra, bioRxiv. (2015).

63. D.L. Greenway, R.R. England, Lett. Appl. Microbiol. 29 (1999) 323-332.

64. D.J. Eaves, V. Ricci, L.J.V. Piddock, Antimicrob. Agents Chemother. 48 (2004) 1145-1150.

65. C. Muller, P. Plesiat, K. Jeannot, Antimicrob. Agents Chemother. 55 (2011) 1211-1221.

66. K. Poole, K. Tetro, Q. Zhao, S. Neshat, D.E. Heinrichs, N. Bianco, Antimicrob. Agents Chemother. 40 (1996) 2021-2028. 
67. M.P. Trotonda, Y.Q. Xiong, G. Memmi, A.S. Bayer, A.L. Cheung, J. Infect. Dis. 199 (2009) 209-218.

68. M.L. Sobel, S. Neshat, K. Poole, J. Bacteriol. 187 (2005) 1246-1253.

69. C. Chen, C.F. Chang, D.W. Hsu, J.C. Shu, H.Y. Chen, C.Y. Chen, C.Y. Lu, C.C. Chen, Int. J. Med. Microbiol. 307 (2017) 521-532.

70. K. Kanehara, K. Ito, Y. Akiyama, Genes Dev. 16 (2002) 2147-2155

71. S. Humphreys, A. Stevenson, A. Bacon, A.B. Weinhardt, M. Roberts, Infect. Immun. 67 (1999) 1560-1568.

72. H.D. Lencastre, S.W. Wu, M.G. Pinho, A.M. Ludovice, S. Filipe, S. Gardete, R. Sobral, S. Gill, M. Chung, A. Tomasz, Microb Drug Resist. 5 (1999) 163-175.

73. R. Hakenbeck, R. Brückner, D. Denapaite, P. Maurer, Future Microbiol. 7 (2012) 395-410.

74. L. Silver, Nat. Rev. Drug. Discov. 6 (2007) 41-55.

75. C. Tamae, A. Liu, K. Kim, D. Sitz, J. Hong, E. Becket, A. Bui, P. Solaimani, K.P. Tran, H. Yang, J.H. Miller, J. Bacteriol. 190 (2008) 5981-5988.

76. E. Recacha, J. Machuca, P. Díaz de Alba, M. Ramos-Güelfo, F. Docobo-Pérez, J. Rodriguez-Beltrán, J. Blázquez, A. Pascual, J.M. Rodríguez-Martínez, mBio. 8 (2017) e00971-17.

77. J.F. Barrett, R.M. Goldschmidt, L.E. Lawrence, et al., PNAS 95 (1998) 53175322.

78. T.L. Harris, R.J. Worthington, C. Melander, Angew. Chem. Int. Ed. Engl. 51 (2012) 11254-11257.

79. F. Khan, Y. Patoare, P. Karim, I. Rayhan, M.A. Quadir, A. Hasnat, Pak. J. Pharm. Sci. 18 (2005) 57-61.

80. B.E. Bunnell, J.F. Escobar, K.L. Bair, M.D. Sutton, J.K. Crane, PLoS ONE. 12 (2017) e0178303.

81. T.J. Wigle, S.F. Singleton, Bioorg. Med. Chem. Lett. 17 (2007) 3249-3253.

82. A. Kali, D. Bhuvaneshwar, P.M.V. Charles, K.S. Seetha, J. Basic Clin. Pharm. 7 (2016) 93-96.

83. Y. Oda, Mutat. Res. 348 (1995) 67-73.

84. P. Bellio, F. Brisdelli, M. Perilli, A. Sabatini, C. Bottoni, B. Segatore, D. Setacci, G. Amicosante, G. Celenza, Phytomedicine 21 (2014) 430-434.

85. S.H. Mun, S.B. Kim, R. Kong, J.G. Choi, Y.C. Kim, D.W. Shin, O.H. Kang, D.Y. Kwon, Molecules 19 (2014) 18283-18295.

86. A. Nautiyal, K.N. Patil, K. Muniyappa, J. Antimicrob. Chemother. 69 (2014) 1834-1843.

87. C.Y. Mo, M.J. Culyba, T. Selwood, et al., ACS Infect. Dis. 4 (2018) 349-359.

88. A. Tkachenko, L. Nesterova, M. Pshenichnov, Arch. Microbiol. 176 (2001) 155157.

89. A. Yakimov, G. Pobegalov, I. Bakhlanova, M. Khodorkovskii, M. Petukhov, D. Baitin, Nucleic Acids Research. 45 (2017) 9788-9796.

90. C. Fuente-Núñez, F. Reffuveille, E.F. Haney, S.K. Straus, R.E. W. Hancock, PLOS Pathogens. 10 (2014) e1004152.

91. S.C. Mansour, D. Pletzer, C. de la Fuente-Nunez, P. Kim, G.Y.C. Cheung, H.S. Joo, M. Otto, R.E.W. Hancock, EBioMedicine 12 (2016) 219-226.

92. D.H. Kwon, C.D. Lu. Antimicrob, Agents Chemother. 51 (2007) 2070-2077.

93. D. Pletzer, H. Wolfmeier, M. Bains, R.E.W. Hancock, Front. Microbiol. 8 (2017) 1867. 
94. S.A. El-Mowafi, E. Sineva, J.N. Alumasa, H. Nicoloff, J.W. Tomsho, S.E. Ades, K.C. Keiler, Antimicrob. Agents Chemother. 59 (2015) 193-205.

95. S.A. El-Mowafi, J.N. Alumasa, S.E. Ades, K.C. Keiler, Antimicrob. Agents Chemother. 58 (2014) 5500-5509.

(C)2018 by the authors; licensee IAPC, Zagreb, Croatia. This chapter is an open-access publication distributed under the terms and conditions of the Creative Commons Attribution license (http://creativecommons.org/licenses/by/3.0/) (cc) BY 
